\title{
THE EFFECTS OF INDUSTRIAL EFFLUENTS ON THE WATER QUALITY OF ABA RIVER IN SOUTH-EASTERN NIGERIA
}

\author{
${ }^{1}$ UBA Uchechukwu Promise, ${ }^{2}$ Dr. Ezekwe Clinton \\ ${ }^{I}$ Department of Geography and Environmental Management, Faculty of Social Sciences, \\ University of Port Harcourt Choba, Port Harcourt. \\ ${ }^{2}$ Department of Geography and Environmental Management, Faculty of Social Sciences, \\ University of Port Harcourt Choba, Port Harcourt.
}

Article DOI: https://doi.org/10.36713/epra7051

DOI No: 10.36713/epra7051

\begin{abstract}
This study examines the effect of industrial effluents on the water quality of the Aba River. In order to achieve this, a total of six water samples were collected each season and was analysed for different wastewater characteristics of temperature, water pH, Conductivity, Alkaline, Chloride, BOD, , COD, DO, TS, THC, TDS, Zn, Cd, Fe, Pb, Cr, Total Coli-form and E-Coli. Using APHA Standard Analytical Method, the results shows that during dry season, temperature, pH, Chloride and Zn values were found to be lower than NESREA Standard. While TS, THC and Total Coli-form values were found to be higher than NESREA standard in dry season
\end{abstract}

KEYWORDS: Water Quality, Industrial Effluents

\subsection{INTRODUCTION}

\subsection{Background of the Study} Industries are established to fulfil the demand of the ever increasing demand of the growing population (FEPA, 1991). This probably explains the reason why industrialization is considered the cornerstone of development strategies. It thus has a significant contribution to economic and human welfare. Hence, it has become a yardstick for placing countries in the League of Nations and an index of its political stature (Adekunle and Eniola, 2008). Industries despite manufacturing useful products also generate waste products in the forms of solid, liquid or gaseous which leads to the creation of hazards, pollution and losses of energy (Taliq et.al, 2006). In other words, industrialization like other human activities that impact on the environment, often results in pollution and degradation.

Worldwide, water bodies are the primary means for disposal of waste, especially the effluents from industries that are near them. Wastes entering these water bodies are both solid and liquid forms (Osibanjo et.al, 2011). This results to contamination and pollution of the water bodies. Thus, water pollution is today a major problem in the global context and it has been suggested that it is the leading worldwide cause of death and disease (Olubinmi \& Ndubuise, 2011; Etem and Onianwa, 2013).

Human activities during the last century have polluted most rivers which happen as a result of spills and leakages of pollutants as well as regular discharge from processing activities. As a result, water bodies which are major receptacles of treated and untreated or partially treated industrial wastes have become highly polluted. Conventional pollutants (e.g. oil and grease), toxic pollutants (e.g. heavy metals, volatile organic compounds) and other non-conventional pollutants (e.g. nitrate, phosphate and ammonia) are often found in industrial wastewater which is often discharged into surface 
water without adequate treatment. Although most of these compounds are present at low concentrations, many of them raise considerable toxicological concerns, particularly when present as components of complex mixtures. Heavy metals and complex organic compounds are the most important contaminants in wastewater effluents that are present in abundance and are toxic (Malik and Ahmed, 2002).

High levels of pollutants in river water cause an increase in biological oxygen demand (BOD), chemical oxygen demand (COD), total dissolved solids (TDS), total suspended solids (TSS), toxic metals such as cadmium (CD), chromium (Cr), nickel (Ni) and lead $(\mathrm{Pb})$ as well as faecal coli-form and hence make such water unsuitable for drinking, irrigation and aquatic life. Increased pollution loads in fresh water bodies increases the nutrient level of water and causes a violent alteration in $\mathrm{pH}$, reduction in oxygen content and high osmotic pressure (Tiwazi and Chaurasia, 2011). The transfers of unfavourable releases from industries are thus detrimental to human and animal health and safety (Adekunle and Eniola, 2008). In 1956, cases of Mata-Bay disease were reported in Japan. The disease affects the brain, causing insanity and leading to death. The cause of the disease was traced to polluted water by industrial effluents containing methyl-mercury (Ci Jun, 1969). In 1970, a cholera epidemic in Jerusalem was traced back to the consumption of salad vegetables irrigated with raw wastewater (Ipeaiyeda and Onianwa, 2011). Similar incident in 1979 was reported in Iraq in which 450 lives were lost and 6,500 persons hospitalized. It was identified as the cause of, the outbreaks of Escherichia Coli (E-Coli) in Canada. Other incidents of water pollution with smaller fatality were reported in 1982 at Niigata, India and Songhua, China. A Cryptosporidium outbreak in Milwaukee, Wisconsin, USA in 1993, which affected approximately 400,000 consumers and caused 54 deaths, was traced to contaminated water. Outbreak of cholera epidemic and other water related diseases were noticed in Nigeria on several occasions (Igomu, 2011).

Despite these prevalent outbreaks, the pressure on the world's water resources is growing (UNESCO, 2012). For example, water usage in North America has increased by approximately $800 \%$ from 1900 to 1995 while global water use in 2000 , was estimated to be nearly three times than in 1950. As demand increases, pollution of surface water has further reduced the availability of fresh water for intended purposes. Report has it that over 5,200 water bodies in the United States do not meet ambient water quality standards for their designated uses as a result of pathogens, while nearly 4,300 are impaired as a result of nutrients, causally linked to failed onsite treatment and disposal systems (Longe and Ogundipe, 2010).

Contributing to the menace of indiscriminate discharges of industrial effluents in receiving water bodies is improper disposal of wastes, particularly in urban centres of most developing countries. Presently open and indiscriminate discharge of effluents in drainages and river banks is one of the most critical problems facing Nigeria, as the volume of industrial waste is growing at an alarming rate. Unfortunately, the country still lacks adequate technology, resources and manpower required to effectively manage these wastes in an environmentally safe manner (Osibanjo et.al, 2011). It is against this background that the present study examines the effects of industrial effluents on Aba River.

The aim of this study is to determine the effects of industrial effluents on the water quality of Aba River. The specific objectives of this study are stated as includes;

1. To determine the extent to which the effluent discharged from selected industries affect the quality of water in Aba River.

2. To compare the characteristics (physical, chemical and biological) of the water of Aba River at different segment (upstream, fallout points and downstream) with NESREA wastewater discharge Limitation Standard.

The following research hypotheses are stipulated;

1. There is no statistical significant difference between physical, chemical and biological characteristics of Aba River at Upstream, Fallout point (discharge point) and downstream segments of the river at different seasons.

2. There is no significant difference in the selected industries wastewater quality discharged into Aba River and NESREA wastewater quality limitation Standard.

\subsection{Study Area}

The study area lies within Aba North and Obioma Ngwa Local Government Area of Abia State, Nigeria. This comprises of Okpulor Umuobo, Eziama and Ogbo communities along the bank of Aba River, with Eziama and Umuohia as fallout points community; Okpulor Umuobo as upstream point community; and Ogbo community as downstream point community along the course of Aba River (Figure 1).

Geographically, the study area lies between latitude $5^{\mathrm{O}} 07^{\mathrm{I}} 00^{\mathrm{II}}$ to $5^{\mathrm{o}} 09^{\mathrm{I}} 10^{\mathrm{II}}$ North and longitude 
$7^{\mathrm{O}} 20^{\mathrm{I}} 00^{\mathrm{II}}$ to $7^{\mathrm{O}} 24^{\mathrm{I}} 00^{\mathrm{II}}$ East which cover the sampled locations for the study (Figure 1). The study area is bounded to the North and west by Osisioma Ngwa Local Government Area, East by Obi-Ngwa Local Government Area, while the south is bounded by
Ogwunagbo Local Government Area (Figure 4).The study area is at the intersection of roads leading to Port Harcourt, Owerri, Umuahia, Ikot Epkene and Ikot Abasi

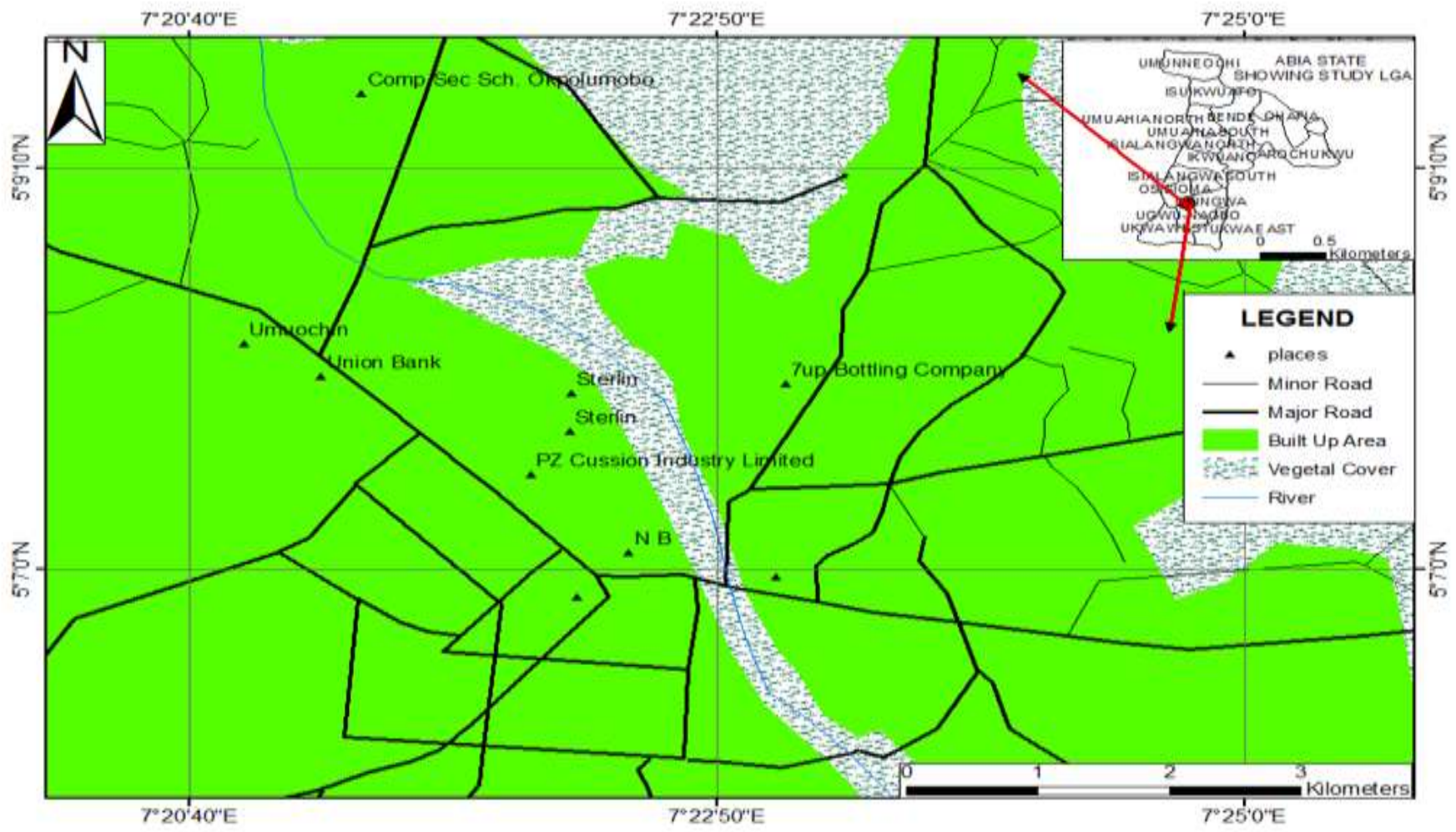

Figure 1: Map of Aba Showing the Study Areas with Insert Abia State Map

Source: Ministry of Land and Survey and Goggle Image. 2019

\subsubsection{Geology and Hydrogeology of the Study} Area

The study area is underlain by Benin formation, consisting of coarse sand interrupted by clay lenses of quaternary age. The Benin formation is a continental deposit of properly upper deltaic depositional environment; the formation is made up of very friable fine to coarse grained sand with minor intercalations of clay and gravel. The Benin Formation is composed mostly of high resistant fresh water bearing continental sand and gravel with clay and shale intercalations (Onyegocha, 1980). The

general thickness of the Benin Formation is variable and ranges from $200 \mathrm{~m}$ at the northeast end to about $2000 \mathrm{~m}$ at the southeast (Avbovbo, 1978), and the main water bearing formation in the area. It has good aquiferous potential. The Aquifer is about $1500 \mathrm{~m}$ thick (Adindu, et.al, 2012). The depths to water are shallow ranging from about $8 m-26 m$ depending on the part of the study area.

\subsection{LITERATURE REVIEW}

\subsection{Review of Relevant Literatures around the} World

A great deal of literature exists on water resource pollution arising from effluent discharges from domestic, industrial and agricultural wastes. Phiri et.al, (2005) assessed the impact of industrial effluents on water quality of receiving rivers in urban areas of Malawi. This they did to assess the extent of chemical pollution in receiving river as affected by industrial effluents. Both the effluents and the water at selected points in the river were analysed for $\mathrm{pH}$, Dissolved Oxygen, Electrical Conductivity, Suspended Solids, Nitrate, Alkalinity, Hardness, Chloride and Phosphate in the dry and rainy seasons. Their findings showed that the effluents were acidic in both the dry season (range: $4.2 \pm 0.02-6.5 \pm 0.02$ ) and in the rainy season (range: $4.2 \pm 0.05-5.6 \pm 0.01$ ). 
While the levels of Dissolved Oxygen, Biological Oxygen Demand, Electrical Conductivity, Suspended Solids, Alkalinity and Chloride were relatively high in the dry and rainy seasons, the concentration of Phosphate and Nitrate were low in both seasons. The water upstream was found to be neutral (average $\mathrm{pH}$, $7.40 \pm 0.04$ ) with high Dissolved Oxygen but low in the levels of the other parameters in both seasons. The water after the effluent receiving points was acidic and the levels of the other parameters were high, especially downstream. The result suggested that the water in the river was polluted and not good for human consumption. It therefore recommends the discouragement of careless disposal of waste water.

A similar study was carried out by the trio of Ghazal et.al (2010), on river Kabul in Pakistan. Like the former, the study evaluates the wastewater characteristics of some major industrial units in terms of Biological Oxygen Demand (BOD), Chemical Oxygen Demand (COD), and Total Suspended Solids (TSS). In achieving this various representative samples were collected from the major industrial units like sugar, paper, ghee (Butter) and textile mills, and were analysed using standard laboratory techniques. The results indicated that the BOD of sugar, paper, ghee (Butter) and textile mills, is in the range of $2235 \mathrm{mg} / 1,1150 \mathrm{mg} / 1,844 \mathrm{mg} / 1$ and $745 \mathrm{mg} / 1$, respectively. Whereas, the COD of sugar, paper, ghee (butter) and textile mills was noticed to be $3945 \mathrm{mg} / \mathrm{l}$, $2045 \mathrm{mg} / \mathrm{l}, 2240 \mathrm{mg} / \mathrm{l}$ and $1244 \mathrm{mg} / \mathrm{l}$ respectively. There was a remarkable increase in the Total Suspended Solids (TSS) from 96 to $382 \mathrm{mg} / \mathrm{l}$ and decrease in Dissolved Oxygen (DO) concentration from 8.8 to $6.7 \mathrm{mg} / \mathrm{l}$. Based on the findings, the authors recommend proper treatment of wastewater coming from industrial source before disposal into River Kabul in order to secure its national water quality.

Tariq et.al, (2006) examined the characteristics of industrial effluents and their possible impacts on quality of underground water. They evaluated the various industrial effluents of Hayatabed Industrial Estate in Peshawar and its possible impacts on quality of ground water. In achieving this, a total of 12 samples including 7 from industrial effluents at the discharge point of each industry, 1 from main drain receiving effluents of all industries and 4 from tube or dug wells in the vicinity of the estate were collected. This was done in March 2003 and analysed for Temperature, pH, Electricity Conductivity, Total Dissolved Solids Total Suspended Solids, Biological Oxygen Demand and Heavy Metal content. The result shows that the characteristics of effluents varied with the industry.
The $\mathrm{pH}$ of one effluent (from Aluminium Industry) was beyond the limit and of the remaining within the permissible limit whereas TSS of one effluent (Pepsi Industries) was within and of the remaining beyond the permissible limits comparing with the National Environmental Quality Standards (NEQS). The BOD was above the permissible limit in almost all of the effluents.

\subsection{Review of Water Pollution Study in Nigeria}

In Nigeria, the input of environmental pollutants in aquatic systems is a common phenomenon and has attracted the attention of scholars. Among them is; Ekhaise and Anyasi (2005). The duo examined the influence of breweries effluent discharge on the microbiological and physiochemical quality of Ikpoba River, Benin city. This they studied to assess the extent of pollution of the water due to effluent discharge from the two brewery industries in Benin City. In achieving this, wastewater sample was collected for bacteriological analysis from five sampling stations along the course of the river, fortnight between March 2004 and May 2004. The samples were collected in new sterile 5 litre plastic containers. Samples for BOD and COD were collected separately in pre-sterilized bottles. The oxygen was fixed in situ by the addition of $1.2 \mathrm{ml}$ each of Winkler's solution A and B. All samples were transported to the laboratory and analysed within 6hours of collection. The result shows that total microbial population counts ranged from $1.0 \times 10^{3}$ to $4.8 \times 10^{3} \mathrm{cfu} / \mathrm{ml}$ and $1.3 \times 10^{7}$ to $5.7 \times 10^{7} \mathrm{cfu} / \mathrm{ml}$ for the fungal and bacterial isolates respectively. Total coli-form counts ranged from $4.3 \times 10 \mathrm{MPN} / 100 \mathrm{ml}$ to $38.0 \times 10 \mathrm{MPN} / 100 \mathrm{ml}$. Microorganisms isolated include saccharomyces cereviceae, Aspergillus niger, Penicillium Sp., Geotrichum Sp., Candida Sp., proteus Sp., Staphylococcus Sp., Echerichia coli, Streptococcus faecalis and bacillus Sp. Physio-chemical parameter studies revealed that Ikpoba River though show some parameters whose values are higher than the WHO acceptable limits. They conclude that there exist contaminations of the surface water due to the brewery effluent discharge.

\subsection{The South-South Geo-Political Zone}

Within the south-south geo-political zone, Nkponyeasua (2010) examined the effect of channelling wastewater into water bodies. This he conducted on the Orogodo River in Agbor, Delta state, Nigeria. He observed that the river which was previously used for carrying out fishing activities is no longer used due to the water pollution which has 
led to the sitting of the river, thereby reducing the size of the water front, depth and volume. This has eliminated one aspect of agriculture for which the Ika people of delta state are known for. He also observed that Orogodo River has lost its true definition of fresh water body as its water is no longer suitable for household use but rather serves as a breeding ground for bacteria, viruses and parasites. He recommended several control measures which include the diversion of run off wastewater from the drainages by considering the use of retention ponds for runoff collection and establishment of wastewater treatment facilities within the state major towns and cities by the government or in partnership with the private sector. He also recommends the massive awareness campaign on the environmental hazards of wastewater through the various forms of media. This he added will help in enlightening the public on their individual roles as regarding wastewater generation and constituents.

Atubi (2011) examined the effects of Warri Refinery effluents on the Iffie River, Delta State, Nigeria. He assessed the nature of effluent released into the river and also the effect of effluent on the water quality. The data used were generated from direct field measurement of $\mathrm{pH}$, Conductivity, Total Hardness, Total Dissolved Solids (TDS), Total Suspended Solids (TSS), Turbidity and Heavy Metal. The results showed that chemical such as Chloride, Phosphate, Oil and Grease, Chromium, Hydrogen Sulphide, Magnesium, Copper, Zinc, Nickel are released into the river. The $\mathrm{pH}$ values of 6.53 mean which is within the WHO acceptable limit of 6.5-92 thresholds were observed. This was observed of other heavy metals such as $\mathrm{Mg}, \mathrm{Zn}, \mathrm{Cr}, \mathrm{Ni}, \mathrm{Cu}, \mathrm{H}_{2} \mathrm{~S}$ etc. However, the Turbidity, Hydrogen Sulphide, Total Suspended Solids (TSS), Copper, Chromium records were found to be higher than the WHO and FEPA (NESREA) standards thereby making the water in these areas not suitable for consumption.

\subsection{The South-East Geo-Political Zone}

In the southeast, a number of studies exist as regards the quality of water (river). Among these is Nkwochaet.al, (2013) who undertook a quality assessment of effluent discharges from vegetable oil plant in Anambra State, South Eastern Nigeria. This was evaluated relative to regulatory Body-Federal Environmental Protection Agency (FEPA) standard. Wastewater quality parameters were determined weekly on effluent samples for a period of 12 weeks, using standard methods. The effluent data were subjected to statistical correlation. The results show BOD values to be in a range of between 10.80-
$94.20 \mathrm{mg} / \mathrm{l}$, with $90 \%$ occurrence value of $81.20 \mathrm{mg} / \mathrm{l}$ which exceed FEPA set limit of $50 \mathrm{mg} / 1$ by $62.40 \%$ for about $14 \%$ of the time. Dissolved Oxygen (DO) level was observed to be in the range of 2.70$4.60 \mathrm{mg} / \mathrm{l}$ which was below the saturation point of $2.5 \mathrm{mg} / 1$ at $30^{\circ} \mathrm{c}$. Total hydrocarbon content (THC) and Oil and grease were found to be higher than the set limit of $10 \mathrm{mg} / \mathrm{l}$. The same applied to $\mathrm{PH}$. However, Total Dissolved Solids (TDS) and Temperature levels were consistently within permissible limit throughout the period of the study. Based on the findings, the authors recommend proper treatment and monitoring of effluent to ensure consistent quality that meets environmental standards.

On the other hand, Egwuonwu et.al, (2012) evaluated the effects of industrial wastewater discharge on surface water with a case study of Nigerian Breweries Plc Enugu into the Ajali River. This was carried out to ascertain the level of Biochemical Oxygen Demand (BOD), Chemical oxygen Demand (COD), Total Suspended Solids (TSS) etc and other characterized effluent been discharged into the river. To achieve this, laboratory analysis was carried out on the Alaji River and the wastewater discharged from the industry and it was confirmed not to have exceeded the benchmark for required discharge of wastewater into streams and rivers as stipulated by regulatory bodies. In conclusion, the authors recommended treatment measures and regulatory policies to checkmate the abuse of this river and the danger it might likely pose.

Ezeronye and Ubalua (2004) examined the effect of abattoir and industrial effluent on water quality of Aba River. In achieving this, the duo of Ezeronye and Ubalua collected water samples from five points: two at upstream at different distance from the abattoir, one from the abattoir discharge point and two from downstream at different distance. Their findings showed that some chemical parameters were below the minimum allowable levels sets by the United State Environmental Protection Agency (USEPA). Nevertheless, there is very little information on the hydrodynamic characteristics of effluent discharges from the point sources through the river course to downstream communities, especially for Aba River. This study therefore explains the effects of spatial dispersion of pollutants concentration along the course of Aba River, as limited studies have been conducted.

\subsection{METHOD}

This study adopted standard methods for examination of water and waste water which is 
established by three organisations, (American Public Health Association, American Water Works Association and Water Environmental Federation) and this is currently regarded as the best water analytical method in America.

Analytical reagent grade of chemicals was used for all forms of analysis, decontamination of laboratory equipment and facilities. Though proper cleaning was ensured, quality control of laboratory air (equipped with functional cooling system), equipment and distilled water were also observed. To guide against lack of sensitivity and calibration, analysis of 'control' (blank) and 'standard '(reference) samples were also regularly carried out to avoid error resulting from Contamination (reagents/materials), lack of sensitive instrument, lack of calibration (human error) and error in data reporting.

Descriptive and inferential statistics were employed to analyse the obtained data in this study. The physiochemical and biological variables of the discharged effluents samples from the selected industries would be explained using mean value. The laboratory experiment results were analysed using mean and standard deviation. The acquired discharge effluent samples (independent) were compare with the Aba River samples (dependent) to ascertain the relationship among the variable using a statistical technique of Analysis of Variance, Chi-Square and Pearson Moment Correlation.

\subsection{RESULT}

\begin{tabular}{|c|c|c|c|c|c|c|c|c|c|c|c|c|c|}
\hline \multirow{2}{*}{$\begin{array}{c}\text { Parameters/Industries } \\
\text { Season }\end{array}$} & \multicolumn{2}{|c|}{ UP Stream } & \multicolumn{2}{|c|}{ STARLINE } & \multicolumn{2}{|c|}{7 UP } & \multicolumn{2}{|c|}{ PZ } & \multicolumn{2}{|c|}{ NB PLC } & \multicolumn{2}{|c|}{ DOWN Stream } & \multirow[t]{2}{*}{ NESREA } \\
\hline & Dry & Rainy & Dry & Rainy & Dry & Rainy & Dry & Rainy & Dry & Rainy & Dry & Rainy" & \\
\hline \multicolumn{14}{|l|}{ PHYSICAL } \\
\hline Temp. (c) & 27.5 & 29.5 & 29 & 29.5 & 28 & 35.6 & 36 & 34.5 & 28 & 31 & 29 & 30.5 & $<3$ \\
\hline $\mathbf{p H}$ & 6.68 & 8 & 6.89 & 9 & 7.52 & 8.8 & 7.1 & 6.3 & 6.59 & 6.6 & 6.94 & 7.3 & $6--9$ \\
\hline Conductivity (um/cm) & 49 & 39 & 173 & 248 & 527 & 610 & 67 & 1224 & 781 & 347 & 62 & 77 & \\
\hline Alkaline $(\mathbf{m g} / \mathbf{L})$ & 4 & 8 & 4 & 14 & 112 & 165 & 7.2 & 125 & 132 & 80 & 6.4 & 18 & \\
\hline TS (mg/L) & 60 & 27.5 & 300 & 143.4 & 1260 & 390 & 60 & 813 & 1220 & 202 & 120 & 61.35 & 10 \\
\hline TDS (mg/L) & 1.5 & 21.5 & 1.5 & 136.4 & 18 & 336 & 1.5 & 673 & 21 & 191 & 6 & 42.35 & \\
\hline \multicolumn{14}{|l|}{ CHEMICAL } \\
\hline Chloride (mg/L) & 6 & 4 & 36 & 18 & 16 & 13 & 12 & 55 & 60 & 15 & 16.8 & 10 & 100 \\
\hline COD (mg/L) & 10 & 0.25 & 60 & 0.3 & 104 & 3.7 & 40 & 3.8 & 88.3 & 4.75 & 32 & 0.25 & 40 \\
\hline BOD $(\mathrm{mg} / \mathrm{L})$ & 18.4 & O. 17 & 33.6 & 0.2 & 30.4 & 2.47 & 22.4 & 2.53 & 32.8 & 3.17 & 32 & O. 167 & 20 \\
\hline DO (mg/L) & 8.64 & 5.78 & 8 & 8.16 & 0.8 & 8.54 & 5.76 & 7.86 & 0.4 & 3.38 & 3.2 & 3.6 & \\
\hline THC (mg/L) & 180 & O & 220 & O & 1480 & O & 280 & O & 560 & O & 100 & O & 10 \\
\hline Zn (mg/L) & 0.015 & 0.03 & 0.08 & O. 171 & 0.08 & 0.1 & 0.01 & O. 1 & 0.06 & 0.21 & 0.015 & 0.074 & 5 \\
\hline Cd (mg/L) & Nil & Nil & Nil & Nil & Nil & Nil & Nil & Nil & Nil & Nil & Nil & Nil & O. 1 \\
\hline Fe $(\mathrm{mg} / \mathrm{L})$ & Nil & 926 & Nil & 0.294 & 2.92 & 2.81 & Nil & 3.31 & 20.5 & 1.62 & Nil & 1.197 & 2 \\
\hline $\mathrm{Pb}(\mathrm{mg} / \mathrm{L})$ & Nil & Nil & Nil & Nil & Nil & Nil & Nil & Nil & Nil & Nil & Nil & Nil & O. 1 \\
\hline $\operatorname{Cr}(\mathrm{mg} / \mathrm{L})$ & Nil & Nil & Nil & Nil & Nil & Nil & Nil & Nil & Nil & Nil & Nil & Nil & 0.01 \\
\hline \multicolumn{14}{|l|}{ BIOLOGICAL } \\
\hline Total coliform & 23 & 2400 & Nil & 240 & 1600 & 2400 & 33 & 2400 & 78 & 2400 & 33 & 2400 & 10 \\
\hline E-coli & Nil & 93 & Nil & 15 & Nil & 2400 & Nil & 2400 & Nil & 2400 & Nil & 2400 & $\mathrm{O}$ \\
\hline
\end{tabular}

Table 1: Result of the Analysis

Nil $=$ Below Detectable Limit.

Source: Researcher's Laboratory Results,

The stated hypotheses were tested using statistical techniques of Two Ways Analysis of Variance (ANOVA) with replication and Chi-square $\left(\mathrm{X}^{2}\right)$ respectively.

\subsection{Hypothesis 1}

Two ways Analysis of Variance (ANOVA) with Replication test procedure produce an analysis for a quantitative dependant variable affected by more than two factors (independent variable). Analysis of variance is used to test the hypothesis that several means are equal; this technique is an extension of the two - sample T-test. Think of it as a generalization of the pooled T-test. Instead of two populations (as in the case of a T-test), there are more than two populations or treatments. Based on these facts we applied it to determine the statistical significant difference between physical, chemical and biological characteristics of Aba River at Upstream, Fallout point (discharge point) and downstream segments and at different season of the year. Thus, two factors (characteristics and segments) were used it to validate our Hypothesis 1 at $95 \%$ confidence level.

Decision Rule: To accept our null hypothesis $\left[\mathrm{H}_{0}\right]$ the result of calculated F-ratio value must be below our theoretical F-ratio value from F-Distribution table, otherwise the null hypothesis $\left[\mathrm{H}_{0}\right]$ is rejected. 
The ANOVA was defined using ANOVA formulae table below.

Table 2: ANOVA FORMULA TABLE

\begin{tabular}{|l|l|l|l|}
\hline VARIATION & Degree of freedom $(\mathrm{df})$ & MEAN SQUARE & $\mathrm{F}$ ratio \\
\hline $\mathrm{V}_{\mathrm{R}}$ Row (Characteristics) & $\mathrm{a}-1$ & $\hat{\mathrm{S}}^{2}{ }_{\mathrm{R}}=\mathrm{V}_{\mathrm{R}} / \mathrm{a}-1$ & $\widehat{\mathrm{S}}^{2}{ }_{\mathrm{R}} / \hat{\mathrm{S}}^{2}{ }_{\mathrm{E}}=\mathrm{F}_{\mathrm{R}}$ \\
\hline $\mathrm{V}_{\mathrm{C}}$ Columns (segment) & $\mathrm{S}_{\mathrm{b}}-1$ & $\hat{\mathrm{S}}^{2}{ }_{\mathrm{C}}=\mathrm{V}_{\mathrm{C}} / \mathrm{S}_{\mathrm{b}}-1$ & $\hat{\mathrm{S}}_{\mathrm{C}} / \hat{\mathrm{S}}^{2}{ }_{\mathrm{E}}=\mathrm{Fc}$ \\
\hline $\mathrm{V}_{\mathrm{I}}$ Interception (Season) & $\mathrm{b}-1$ & $\hat{\mathrm{S}}_{\mathrm{I}}{ }_{\mathrm{I}}=\mathrm{V}_{\mathrm{I}} /(\mathrm{a}-1)$ & $\hat{\mathrm{S}}_{\mathrm{I}}{ }_{\mathrm{I}} / \hat{\mathrm{S}}_{\mathrm{E}}{ }_{\mathrm{E}}=\mathrm{F}_{\mathrm{I}}$ \\
\hline $\mathrm{V}_{\mathrm{S}}$ Sub Total & $\mathrm{a}-1+\mathrm{S}_{\mathrm{b}}-1+\mathrm{b}-1$ & & \\
\hline $\mathrm{V}_{\mathrm{E}}$ Residual & $(\mathrm{ab}-1)-\mathrm{V}_{\mathrm{S} \text { df }}$ & $\hat{\mathrm{S}}_{\mathrm{E}}{ }_{\mathrm{E}}=\mathrm{V}_{\mathrm{I}} /(\mathrm{ab}-1)-\mathrm{V}_{\mathrm{S} \text { df }}$ & \\
\hline V Total & $\mathrm{ab}-1$ & & \\
\hline
\end{tabular}

Where $V_{R}=$ Row Variance (Characteristics)

$\mathrm{V}_{\mathrm{C}}=$ Column Variance (segment)

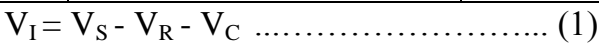

$\mathrm{V}_{\mathrm{E}}=$ Error or Residual Variance

$\mathrm{V}=$ Total Variance

$\mathrm{V}_{\mathrm{S}}=$ Sub Total

$\mathrm{V}_{\mathrm{I}}=$ Interception (Season)

$\mathrm{a}=$ Row Frequency

$\mathrm{V}_{\mathrm{E}}=\mathrm{V}-\left(\mathrm{V}_{\mathrm{C}}+\mathrm{V}_{\mathrm{R}}+\mathrm{V}_{\mathrm{I}}\right)$

$\mathrm{b}=$ Column Frequency

$\mathrm{V}_{\mathrm{R}}=9731884.575, \mathrm{~V}_{\mathrm{C}}=992631.85$,

$\mathrm{V}_{\mathrm{E}}=480367.47, \mathrm{~V}=23188752.95$,

$\mathrm{V}_{\mathrm{S}}=19080563.11, \mathrm{~V}_{\mathrm{I}}=8356046.685$,

$\mathrm{a}=15, \mathrm{~S}_{\mathrm{b}}=2$

Table 3:ANOVA RESULTS TABLE

\begin{tabular}{|c|c|c|c|}
\hline Variation & Degree of Freedom (df) & Mean Square & F ratio \\
\hline $\mathrm{V}_{\mathrm{R}}=9731884.575$ & $\mathrm{a}-1=14$ & $\hat{\mathrm{S}}_{\mathrm{R}}{ }_{\mathrm{R}}=695134.6125$ & $\mathrm{~F}_{\mathrm{R}}=10.1524$ \\
\hline $\mathrm{V}_{\mathrm{C}}=992631.85$ & $\mathrm{~S}_{\mathrm{b}}-1=1$ & $\hat{\mathrm{S}}^{2}{ }_{\mathrm{C}}=992631.85$ & $\mathrm{~F}_{\mathrm{C}}=14.4974$ \\
\hline $\mathrm{V}_{\mathrm{I}}=8356046.685$ & $\mathrm{~b}-1=14$ & $\hat{\mathrm{S}}_{\mathrm{I}}=596860.4775$ & $\mathrm{~F}_{\mathrm{I}}=8.7171$ \\
\hline $\mathrm{V}_{\mathrm{S}}=19080563.11$ & $\mathrm{a}-1+\mathrm{S}_{\mathrm{b}}-1+\mathrm{b}-1=29$ & & \\
\hline $\mathrm{V}_{\mathrm{E}}=480367.47$ & $(\mathrm{ab}-1)-\mathrm{V}_{\mathrm{S} d f}=60$ & $\hat{\mathrm{S}}_{\mathrm{E}}{ }_{\mathrm{E}}=68469.8307$ & \\
\hline $\mathrm{V}=23188752.95$ & $\mathrm{ab}-1=89$ & & \\
\hline
\end{tabular}

From the table 3 above, Calculated $F_{R}$ value $(10.1524)$ is greater than the theoretical value $\left(\mathrm{F}_{.95}=\right.$ $1.92)$ at the $95 \%$ confidence level with 14 and 60 degree of freedom. Thus 10.1524 is greater than (>) 1.92 , therefore we reject the null hypothesis $\left[\mathrm{H}_{0}\right]$. That states that there is no significant difference between physical, chemical and biological characteristics of Aba River, and uphold alternative hypothesis $\left[\mathrm{H}_{1}\right]$ which states that there is significant difference between physical, chemical and biological characteristics of Aba River. Since the calculated $\left(\mathrm{F}_{\mathrm{C}}\right.$ $=14.4974)$ value is greater than theoretical value $\left(\mathrm{F}_{.95}\right.$ $=4.0)$ at the $95 \%$ confidence level with 1 and 60 degree of freedom. Thus, $\mathrm{F}_{\mathrm{C}}=14.4974>4.0$, therefore, we reject the null hypothesis $\left[\mathrm{H}_{0}\right]$. Thus, the Upstream, Fallout point (discharge point) and downstream segments of Aba River varies in quality. On the other hand, the calculated $\left(\mathrm{F}_{\mathrm{I}}=8.7171\right)$ value is greater than the theoretical value (1.92) at $95 \%$ probability level with 14 and 60 degree of freedom. Arising from this we reject null hypothesis $\left[\mathrm{H}_{0}\right]$ and accept the alternate hypothesis $\left[\mathrm{H}_{\mathrm{I}}\right]$. Thus, there is statistical significant variation between observed in characteristics (Physical, Chemical and Biological) at

upstream, fallout points and downstream segments of Aba River in different seasons of the year.

\subsection{Hypothesis 2}

Chi-square $\left(\mathrm{X}^{2}\right)$ test is a statistical tool used to examine differences between nominal or categorical variables. The chi-square test is used to estimate how closely an observation distribution matches an expected distribution, known as the Goodness of Fit Test. This was applied to this section to determine the significant difference in the selected industries wastewater quality discharged into Aba River and NESREA wastewater quality Standard, at 95\% probability levels.

For the purpose of this analysis we use the observed effluent parameters of the sampled industry as our observation $(\mathrm{O})$ and the NESREA industrial effluent limitation standard as expected parameter (E) as shown in Table 4.6

The chi-square $\left(\mathrm{X}^{2}\right)$ statistics is defined as:

$\Sigma(\mathrm{O}-\mathrm{E})^{2} / \mathrm{E}$

And the degree of freedom

(df) as $\mathrm{N}-1$

Where $\mathrm{n}=$ frequency of observation. 
Decision rule: To accept null hypothesis $\left[\mathrm{H}_{0}\right]$ the result calculated $\mathrm{X}^{2}$ must be lower than chi-square $\left[\mathrm{X}^{2}\right]$ distribution value from table otherwise the $\mathrm{H}_{0}$ is rejected. The computation is based on 0.01 and 0.05 confidence level.
The table 4.7 indicates the industries effluent parameter of sampled industries with the corresponding NESREA effluent limitation standard for industries. The computation of the chi-square $\left(\mathrm{X}^{2}\right)$ is fully expressed in appendix 3 and the outcome is summarized in table below.

Table 4: SUMMARY OF CHI-SQUARE RESULT

\begin{tabular}{|c|c|c|c|c|c|c|c|}
\hline INDUSTRY & \multicolumn{2}{|c|}{${\text { COMPUTED } \mathrm{X}^{2}}^{2}$} & \multicolumn{2}{|c|}{ THEORITICAL $\mathbf{X}^{2}$} & \multicolumn{2}{|c|}{ DF } & REMARK \\
\hline & $\begin{array}{l}\text { DRY } \\
\text { SEASON }\end{array}$ & $\begin{array}{l}\text { RAINY } \\
\text { SEASON }\end{array}$ & $\begin{array}{l}\text { DRY } \\
\text { SEASON }\end{array}$ & $\begin{array}{l}\text { RAINY } \\
\text { SEASON }\end{array}$ & D & $\mathbf{R}$ & \\
\hline STARLINE & 12885.12 & 7202.52 & 18.5 & 20.1 & 7 & 8 & $\mathrm{H}_{0}$ not accepted \\
\hline 7 UP & 652335.16 & 585742.47 & 21.7 & 20.1 & 9 & 8 & $\mathrm{H}_{0}$ not accepted \\
\hline PZ CUSSION PLC & 7676.59 & 635797.56 & 20.1 & 20.1 & 8 & 8 & $\mathrm{H}_{0}$ not accepted \\
\hline NB PLC & 177380.46 & 575012.81 & 21.7 & 20.1 & 9 & 8 & $\mathrm{H}_{0}$ not accepted \\
\hline MEAN & 119591.24 & 356572.77 & 21.7 & 20.1 & 9 & 8 & $\mathrm{H}_{0}$ not accepted \\
\hline
\end{tabular}

Table 4 above, it is evident that computed $\mathrm{X}^{2}$ values of all the studied industries wastewater at various season are above the theoretical values in both 0.01 confidence level, therefore null hypothesis $\left[\mathrm{H}_{0}\right]$ is rejected. Thus, alternate hypothesis $\left[\mathrm{H}_{1}\right]$ is accepted. In conclusion, there is statistical significant difference in the selected industries wastewater quality discharged into Aba River and NESREA waste water Quality Limitation Standard.

\subsection{CONCLUSION}

This study indicates that there is an increase in most of the characteristics used to evaluate the effect of industrial effluents on water quality of Aba River and most of these characteristics are high above NESREA stipulated standard, it also reveals that there is statistical significant difference in characteristics of Aba River water sample at different segment and different season of the year, and that the effluents from these selected industries statistically varies significantly from stipulated standard set by NESREA and further shows that there is a statistical significant correlation between Aba River water quality at upstream and downstream segment in both dry and rainy season, that the variation in dry season and rainy season are $61.5 \%$ and $49.6 \%$ respectively, so we therefore conclude that:

\subsection{Aba River is contaminated}

The result of the physical, chemical and biological analysis of this study shows that Aba River is polluted and this could be hazardous to health. The source of the observed contamination is from industrial effluents discharges into the water body.
Thus the result of the physiochemical and biological analysis of the river shows that industrial effluents being discharged into the Aba River impact negatively on its water quality, therefore it is unsafe to exploit water from the river for human consumption without any form of treatment.

\subsection{Deterioration of Aba River Water}

The study shows that pollution level of Aba River could be on increase if left uncheck, this will affect the use of the water. The levels of most parameters studied were generally higher at fallout point and downstream than the level obtained in the upstream segment of the river. Although, the values of some parameters are low compare to permissible limit set by NESREA. Continual discharge of industrial effluents without proper treatment into the river may result to accumulation of these contaminants.

\subsection{RECOMMENDATION}

Based on the findings the following recommendations are put forward to check industrial effluent discharge into Aba River.

1. Industries should be committed to environmental safety, particularly water body by ensuring that the wastewater they generate undergoes proper treatment before discharging to water body.

2. The government through NESREA should ensure that industries establish wastewater treatment plant to their industry. They should also ensure efficient environmental laws as well as social awareness for 
residents along the river course to educate them on the potential threat to industrial effluents.

\subsection{REFERENCES}

1. Adekunle, A. S. \& Eniola, I. T. K. (2008). Impact of Industrial Effluents on Quality of Segments of Asa River within an Industrial Estate in Illorin, Nigeria. New York Science Journal, 1(1), 17-21.

2. Adindu, R. U., Igboekwe, M. U. \& Lebe, N. (2012). Ground water Mineralization Analysis of Osisioma Local Government Area of Aba, Abia State, Nigeria. America Journal of Chemistry, 2(3), 121-125.

3. Atubi, A. O. (2011). Effect of Warri Refinery Effluents on Water Quality from the Iffie River, Delta State, Nigeria. America Review of Political Economy. 45-50.'

4. Avbovbo, A. A. (1978). Tertiary Lithostratigraphy of Niger Delta. Bulletin, America Association of geologist, 1978 63:297-306.

5. Ci Jun. (1969). Mina Mata disease and water pollution on industrial wastes. Review International Ocean Organisations. Med. Nos. 13-14.

6. Egwuonwu, C. C., Uzoije, A. P., Okafor, V. C., Ezeanya, N. C. \& Nwachukwu, M. U. (2012). Evaluation of the Effects of Industrial Wastewater Discharge on Surface water (A Case Study of Nigeria Breweries PLC, Enugu). Greener Journals of Physical Sciences, 2(3), 056-063.

7. Ekhaise, F. O. \& Anyasi, C. C. (2005). Influence off Breweries Effluent Discharge on the Microbiological and Physiochemical quality of Ikpoba River, Nigeria. African Journal of biotechnology, 4(10), 1062-1065.

8. Etim, E. U. \& Onianwa, P. C. (2013). Impact of Effluents of Industrial Estate on Oruku River in South western Nigeria. World Applied Science Journal, 12(7), 1075-1083.

9. Ezeronye O. U. \& Ubalua A. O. (2004). Study on the Effect of Abattoir and Industrial Effluent on the Heavy Metals and Microbial Quality to Aba River in Nigeria. Online at http:www.academicjournals.org/AJB ISSN 16845315, 2005 Academic Journals.

10. Federal Environmental Protection Agency (1991). Guideline and Standard for Environmental Pollution Control in Nigeria FG press 228pp.

11. Ghazal, N., Mohammed, U., Kashif, A. K. \& Attiq, U. R. (2011). Impact of Industrial; Effluents on River Kabul. Hydronepal, 8, 44-47.

12. Igomu T. (2011). Cholera Epidemic Far from Being over NBF news. www.nigeriabestforum.com/blog/? $=60321$ Accessed on 7th march 2015.

13. Ipeaiyeda, A. R. \& Onianwa, P. C. (2011). Pollution Effect of Food and Beverages Effluents on the Alaro River in Ibadan city, Nigeria. Bulletin of Chemical Society of Ethiopia, 25(3), 347-360.

14. Longe, E. O. \& Ogundipe, A. O. (2010). Assessment of Wastewater Discharge Impact from a Sewage Treatment Plant on Lagoon Water, Lagos, Nigeria. Research Journal of Applied Sciences, Engineering and Technology, 2(3), 274-282.

15. Malik, A. \& Ahmad, M. (2002). Seasonal Variation in Bacterial Flora of the Wastewater and Soil in the vicinity of Industrial Area. Environmental Monitory and Assessment, 7(3), 263-273.

16. Nkonyeasua, K. E. (2010). Effect of Channelling Wastewater into Water Bodies: A Case Study of the Orogodo River in Agbor, Delta State. Journal of Human Ecology, 31(1), 47-52.

17. Nkwocha, A. C., Ekeke, I. C., Kamen, F. I. \& Oghome, P. I. (2013). Quality Assessment of Effluent Discharges from Vegetable Oil Plant. Ethopian Journal of Environmental Studies and Management, 6, 717-723.

18. Olubunmi A. N. \& Ndubuise A. (2011): Impact of Industrial Effluent and Dumbsite Leachate Discharge on the Quality of Ground Water in Oyo State, Nigeria. Journals of Biodiversity and Environmental Sciences Vol.1 No. 3 P 13-18.

19. Onyeagocha, A. C. (1980). Petrography and Depositional Environment of Benin Formation, Nigerian Journal of Mining and Geology, 17,147151.

20. Osibanjo, O., Daso, A. P. \& Gbadebo, A. M. (2011). The impact of industrial estate, Ibadan, Nigeria. African Journal of Biotechnology, 10(4), 696-702.

21. Phiri, O., Mumba, P., Moyo, B. H. Z. \& Kadewa, $W$. (2005). Assessment of the Impact of Industrial Effluents on Water Quality of Receiving Rivers in Urban areas of Malawi. International Journal of Environmental Science and Technology, 2(3), 237-244.

22. Tariq M., Ali M. \& Shah Z. (2005). Characteristics of Industrial Effluents and their Possible Impacts on Quality of Underground Water. Journals of Soil and Environmental Science 25(1), 64-69

23. UNESCO (2012): United Nation World Water Development Report. United Nation Education, Scientific and Cultural Organization on Climate Change, Water development Report. 25th March 2012. Unescopress. 